\title{
ANATOMICAL RESPONSE OF WHEAT CULTIVARS TO DROUGHT STRESS
}

\author{
David O.A. ${ }^{1}$, Osonubi O. ${ }^{2}$, Olaiya C. O. ${ }^{3}$, Agbolade J. O. ${ }^{4}$, Ajiboye A. A. ${ }^{5}$ Komolafe R. J. ${ }^{6}$ \\ Chukwuma D.M. ${ }^{7}$ and Akomolafe G.F ${ }^{8}$ \\ ${ }^{1,4,5,6,7}$ Department of Plant Science and Biotechnology, Federal University Oye-Ekiti, Ekiti State, Nigeria. Email: \\ honeycrown1@gmail.com \\ ${ }^{2}$ Department of Botany, University of Ibadan, Ibadan, Nigeria \\ ${ }^{3}$ Department of Biochemistry, University of Ibadan, Ibadan, Nigeria \\ ${ }^{8}$ Department of Botany, Federal University Lafia, Lafia, Nasarawa State, Nigeria \\ Corresponding email: honeycrown1@gmail.com \\ (Received: $14^{\text {th }}$ August, 2017; Accepted: $2^{\text {nd }}$ October, 2017)
}

\begin{abstract}
The study was carried out to investigate the responses of drought stress on wheat tissues. Five wheat cultivars, Alta 84 (AL), Atila (AT), Cettia (CE), Norman Bourgluk 2008 (NB) and Seri M82 (SE) were cultivated. Four weeks after planting, healthy plants were subjected to four treatments viz- well-watered (D1), watered daily, drought stress (D2), one weekly watering, drought stress (D3), two weekly watering and drought stress (D4), and three weekly watering. The experiment was a factorial experiment conducted in a completely randomized design (CRD) with three replicates; Transverse section (TS) of the leaves collected were sectioned using microtome, stained and observed under compound microscope. Mesophyll cells, vascular bundles, bundle sheaths and xylem tissues were measured using ocular micrometer. Epidermal peels were prepared to determine the number of stomata and trichomes. When drought stress was imposed (D2, D3 and D4), wheat cultivar Cettia developed larger mesophyll cells, xylem tissues, vascular bundles and bundle sheaths than other cultivars. Thus, larger vascular bundles would facilitate faster movement of water and mineral salts up to the shoot from the root. Cultivar Atila developed higher number of trichomes during drought stress D2 than other cultivars which help to reduce the rate of transpiration of water out of the epidermal leaves. Wheat cultivars Cettia and Atila could be drought tolerant cultivars. Generally, wheat cultivars developed stable stomata number and stomata closure mechanism to cope with drought stress. There was an increase in number of trichomes at D2, D3 and D4 which revealed the ecologically adaptation of wheat plants to drought stress.
\end{abstract}

Key words: Wheat Cultivars, Drought Stress, Anatomical Structures.

\section{INTRODUCTION}

Wheat belongs to a family called Poaceae and is one of the most important cereal crops. Wheat crops are staple human foods and the straw as fodder for livestock. Wheat grain contains more than half of their calories and nearly half of their protein (Rajaman, 2011). Soil types and water are abiotic factors that bring about variation in growth, yield, physiological and anatomical structure of wheat plants. Soil properties and types vary across farm fields, causing spatial variability in crop yields (Rockström et al., 1999). Spatial variability in soil physical and chemical properties can have influence on the spatial distribution of crop productivity potential (Gaston et al., 2011).

To be able to grow, plants need to take up water from the soil and $\mathrm{CO}_{2}$ from the atmosphere and use it in photosynthesis. This is done by $\mathrm{CO}_{2}$ uptake through the stomatal pore, where water is simultaneously transpired. When the stomata are open, $\mathrm{CO}_{2}$ is taken up while water is transpired. When the stomata are closed little, $\mathrm{CO}_{2}$ is taken up and the transpiration is lowered. By opening and closing the stomata, plants can regulate the amount of water lost, by sacrificing $\mathrm{CO}_{2}$ uptake, when the environmental conditions are unfavorable (Arve et al., 2011). With regard to drought, among the most possible indicators of water requirement in plant are stomata and trichomes (Adulrahaman, 2009). Drought may influence trichomes formation and structures of stomata (Nagata et al., 1999; Höglund and Larsson, 2005)

Trichomes are hair-like appendages that develop from cells of the upper and lower epidermis found in most plant species (Werker, 2000). The structure of trichomes can range from unicellular to multicellular, and the trichomes can be straight, spiral, hooked, branched, or un-branched 
(Southwood, 1986). Trichomes may thus have functions in response to variation in several environmental factors. Trichomes density can be expected in environments that are dry or cold, where solar radiation is intense (Løe et al., 2007). Most ecological studies suggest that plant growing under stress tend to possess leaves that have more trichomes and sunken stomata than similar or related plants from normal conditions (Amzat et al., 2009). Drought stress brings about variation in size of mesophyll cells of accessions of wheat with stability in number of stomatal and vascular bundle area (Hammed et al., 2002). Most plants therefore have some adaptation or response to enhance the growth and survival rate during drought and subsequent recovery. This study was designed to investigate the response of leaf anatomy to drought and soil properties.

\section{MATERIAL AND METHODS Seed Preparation}

Five (5) wheat cultivars, which were Alta 84 (AL), Atila (AT), Cettia (CE), Norman Bourgluk 2008 (NB) and Seri M82 (SE) were bought from Lake Chad Research Institute, Maiduguri, Nigeria. They were rinsed three times in a $10 \%$ sodium hypochlorite solution and then several times with deionized, distilled water to ensure surface sterility.

\section{Soil Sample Collection and Preparation}

Sandy loam was collected at Abagu in Nasarawa State, Nigeria. Soil collected were air-dried for seven days; and sieved through $2 \mathrm{~mm}$ mesh to remove debris and stones from the soil samples.

\section{Location and Experimental Layout}

The experiment was conducted in a screen-house located in Nasarawa State, Nigeria. Three kilogram of air-dried sieved surface soil was filled into labeled perforated plastic pots. Sterilized seeds were sown into plastic pots filled with three soils from different locations in Nasarawa State, Nigeria). Two weeks after planting (WAP), seedlings were thinned to three plants per pot. Four weeks after planting, healthy plants were randomly assigned to each of the four treatments -wellwatered (D1): watered daily; drought stress (D2): one weekly watering; drought stress (D3): two weekly watering; drought stress (D4): three weekly watering. Each pot was watered to field moisture capacity.
The experiment was factorized in completely randomized design (CRD) with three replicates. Fresh leaves were also collected and stored in 70\% ethanol for anatomical studies. Experiment was terminated 12 WAP.

\section{Anatomy Studies}

Transverse sections of leaf tissues were made using microtome and stored in 70\% ethanol until use. Transverse section and leaf epidermis were stained with Safranin O, counter stained with Alcian blue, placed inside $70 \%$ and $80 \%$ ethanol for 30 minutes for decolourization and then mounted in $25 \%$ glycerol. Anatomical parameters viewed and measured were mesophyll thickness, diameter of xylem, bundle sheaths and vascular bundles. Epidermal peels were stained methyl blue for five minutes (5 mins) to determined number of stomata and trichomes. Measurements of various cells and tissues were done using ocular micrometer under compound microscope. Number of stomata and trichomes were counted per unit surface area.

Number of stomata and trichomes were analyzed using error bars at $0.05 \%$ significant level while other anatomical parameters were subjected to Duncan Multiple Range Test using SAS, 2001.

\section{RESULTS}

Wheat Cettia cultivar had the widest bundle sheaths and xylem at drought stress D2 and D4 respectively (Tables 1, 2 and figures 3, 4). Whereas, Seri M82 (SE), Norman Bourgluk 2008 (NB) and Alta 84 (AL) cultivars showed no significant differences in xylem and bundle sheath diameter (Tables 1 and 2 and figures 5, 6,7). With respect to drought stress, there was a significant difference in the size of xylem tissue. Cettia cultivar showed a wider mesophyll thickness and vascular bundles in the drought stress D4 than the other cultivars (Table 4). For all the cultivars, number of stomata showed no significant difference apart from cultivars Cettia under a well-watered (D1) treatment (Figure 2). The Mesophyll cells were well compacted with no intercellular space. Trichomes were highly developed in drought stress D2 in cultivars AL, AT and NB at both the abaxial and adaxial surfaces of the leaves. Although, Atila cultivar recorded highest number of trichomes at the lower (abaxial) and upper (adaxial) epidermis in D2 treatment. Except for cultivar SE, there was a 
profuse development of trichomes (Figure 1) on stress plant but more on the adaxial surfaces. both abaxial and adaxial surfaces under drought

Table 1. Effect of Drought Stress on Bundle Sheath Diameter $(\mu \mathrm{m})$ of Wheat Cultivars

\begin{tabular}{lllllll}
\hline $\begin{array}{l}\text { Drought } \\
\text { Levels }\end{array}$ & AL & AT & CE & NB & SE \\
\hline D1 & $0.70 \mathrm{~b}$ & $0.75 \mathrm{a}$ & $0.63 \mathrm{~d}$ & $0.70 \mathrm{~b}$ & $0.60 \mathrm{~b}$ \\
$\mathrm{D} 2$ & $1.00 \mathrm{a}$ & $0.65 \mathrm{~b}$ & $1.10 \mathrm{a}$ & $0.85 \mathrm{a}$ & $0.60 \mathrm{~b}$ \\
\hline $\mathrm{D} 3$ & $0.63 \mathrm{c}$ & $0.65 \mathrm{~b}$ & $0.74 \mathrm{bc}$ & $0.65 \mathrm{bc}$ & $0.50 \mathrm{c}$ \\
$\mathrm{D} 4$ & $0.40 \mathrm{~d}$ & $0.65 \mathrm{~b}$ & $0.78 \mathrm{~b}$ & $0.40 \mathrm{~d}$ & $0.67 \mathrm{a}$ \\
\hline
\end{tabular}

Means within each column followed by different letters are significantly different at $\mathrm{P}<0.05$ according to Duncan's multiple range tests.

Table 2. Effect of Drought Stress on Xylem Diameter $(\mu \mathrm{m})$ of Wheat Cultivars

\begin{tabular}{cccccc}
\hline $\begin{array}{c}\text { Drought } \\
\text { Levels }\end{array}$ & AL & AT & CE & NB & SE \\
\hline D1 & $1.20 \mathrm{~b}$ & $1.65 \mathrm{a}$ & $1.38 \mathrm{c}$ & $1.50 \mathrm{a}$ & $1.70 \mathrm{a}$ \\
D2 & $1.50 \mathrm{a}$ & $1.15 \mathrm{e}$ & $1.05 \mathrm{~d}$ & $1.50 \mathrm{a}$ & $1.45 \mathrm{~b}$ \\
\hline D3 & $1.18 \mathrm{~b}$ & $1.53 \mathrm{ab}$ & $1.41 \mathrm{~b}$ & $1.30 \mathrm{~b}$ & $1.00 \mathrm{~d}$ \\
D4 & $1.00 \mathrm{c}$ & $1.15 \mathrm{c}$ & $1.55 \mathrm{a}$ & $1.00 \mathrm{c}$ & $1.37 \mathrm{c}$ \\
\hline
\end{tabular}

Means within each column followed by different letters are significantly different at $\mathrm{P}<0.05$ according to Duncan's multiple range tests.

Table 3. Effect of Drought Stress on Vascular Bundle Diameter $(\mu \mathrm{m})$ of Wheat Cultivars

\begin{tabular}{cccccc}
\hline $\begin{array}{c}\text { Drought } \\
\text { Levels }\end{array}$ & AL & AT & CE & NB & SE \\
D1 & $4.35 \mathrm{~b}$ & $5.50 \mathrm{a}$ & $4.60 \mathrm{~b}$ & $6.00 \mathrm{a}$ & $6.00 \mathrm{a}$ \\
$\mathrm{D} 2$ & $5.00 \mathrm{a}$ & $4.05 \mathrm{~b}$ & $4.00 \mathrm{c}$ & $4.60 \mathrm{c}$ & $5.05 \mathrm{~b}$ \\
\hline $\mathrm{D} 3$ & $4.59 \mathrm{~b}$ & $5.20 \mathrm{a}$ & $5.30 \mathrm{a}$ & $5.30 \mathrm{~b}$ & $3.50 \mathrm{~d}$ \\
$\mathrm{D} 4$ & $4.00 \mathrm{~d}$ & $4.25 \mathrm{~b}$ & $5.32 \mathrm{a}$ & $4.00 \mathrm{~d}$ & $4.77 \mathrm{c}$ \\
\hline
\end{tabular}

Means within each column followed by different letters are significantly different at $\mathrm{P}<0.05$ according to Duncan's multiple range tests.

Table 4. Effect of Drought Stress on Mesophyll Thickness ( $\mu \mathrm{m})$ of Wheat Cultivars

\begin{tabular}{cccccc}
\hline $\begin{array}{c}\text { Drought } \\
\text { Levels }\end{array}$ & AL & AT & CE & NB & SE \\
\hline D1 & $3.85 \mathrm{a}$ & $2.65 \mathrm{~b}$ & $3.90 \mathrm{~b}$ & $5.00 \mathrm{a}$ & $4.10 \mathrm{a}$ \\
D2 & $2.95 \mathrm{~b}$ & $2.35 \mathrm{c}$ & $3.00 \mathrm{c}$ & $1.80 \mathrm{~d}$ & $2.40 \mathrm{c}$ \\
\hline D3 & $1.79 \mathrm{c}$ & $3.30 \mathrm{a}$ & $2.26 \mathrm{~d}$ & $3.75 \mathrm{~b}$ & $3.00 \mathrm{~b}$ \\
D4 & $3.00 \mathrm{~b}$ & $2.30 \mathrm{c}$ & $5.57 \mathrm{a}$ & $3.00 \mathrm{c}$ & $2.40 \mathrm{c}$ \\
\hline
\end{tabular}

Means within each column followed by different letters are significantly different at $\mathrm{P}<0.05$ according to Duncan's multiple range tests. 

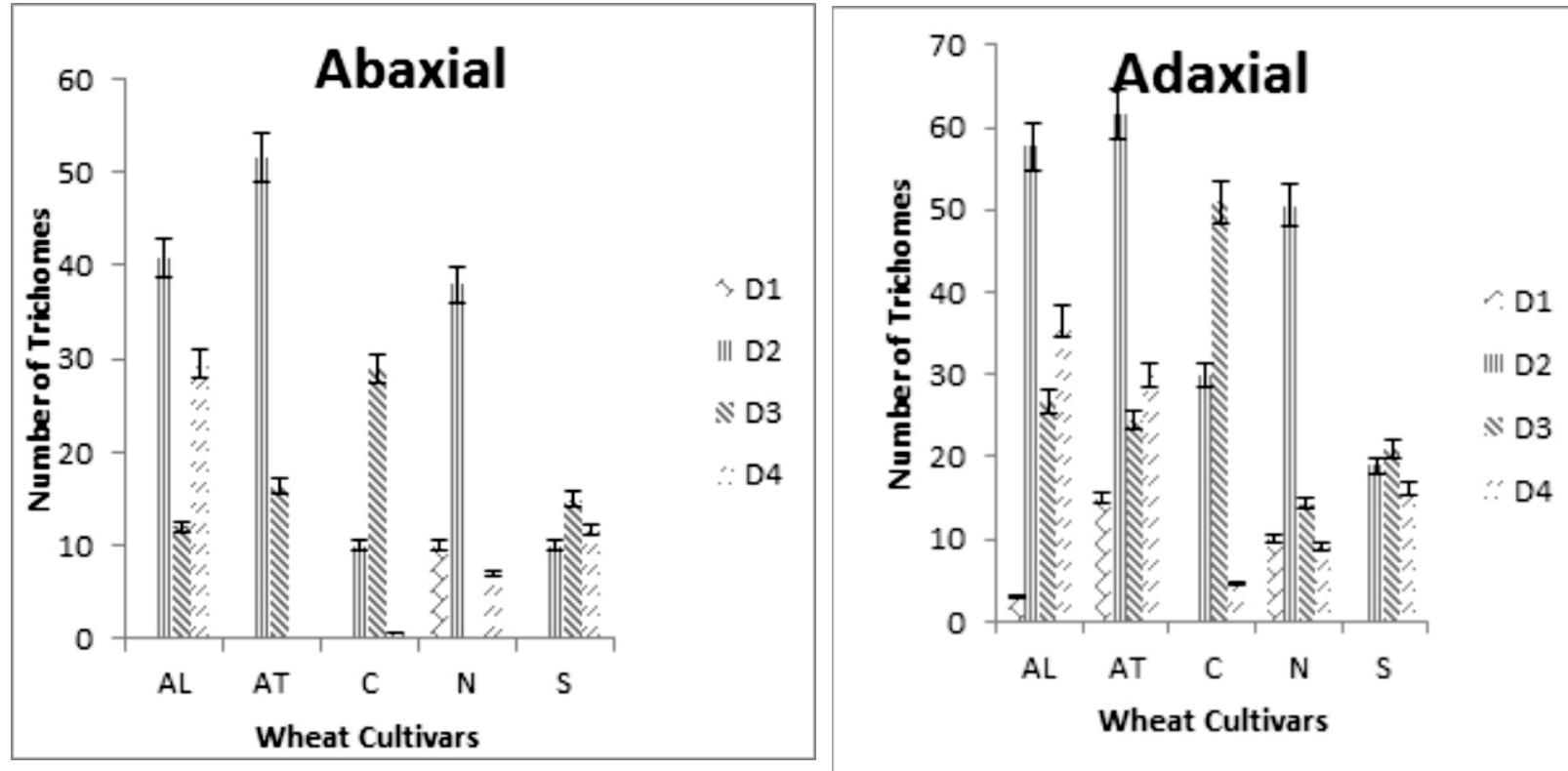

Figure 1: Response of Trichomes to Drought stress per unit area of surface

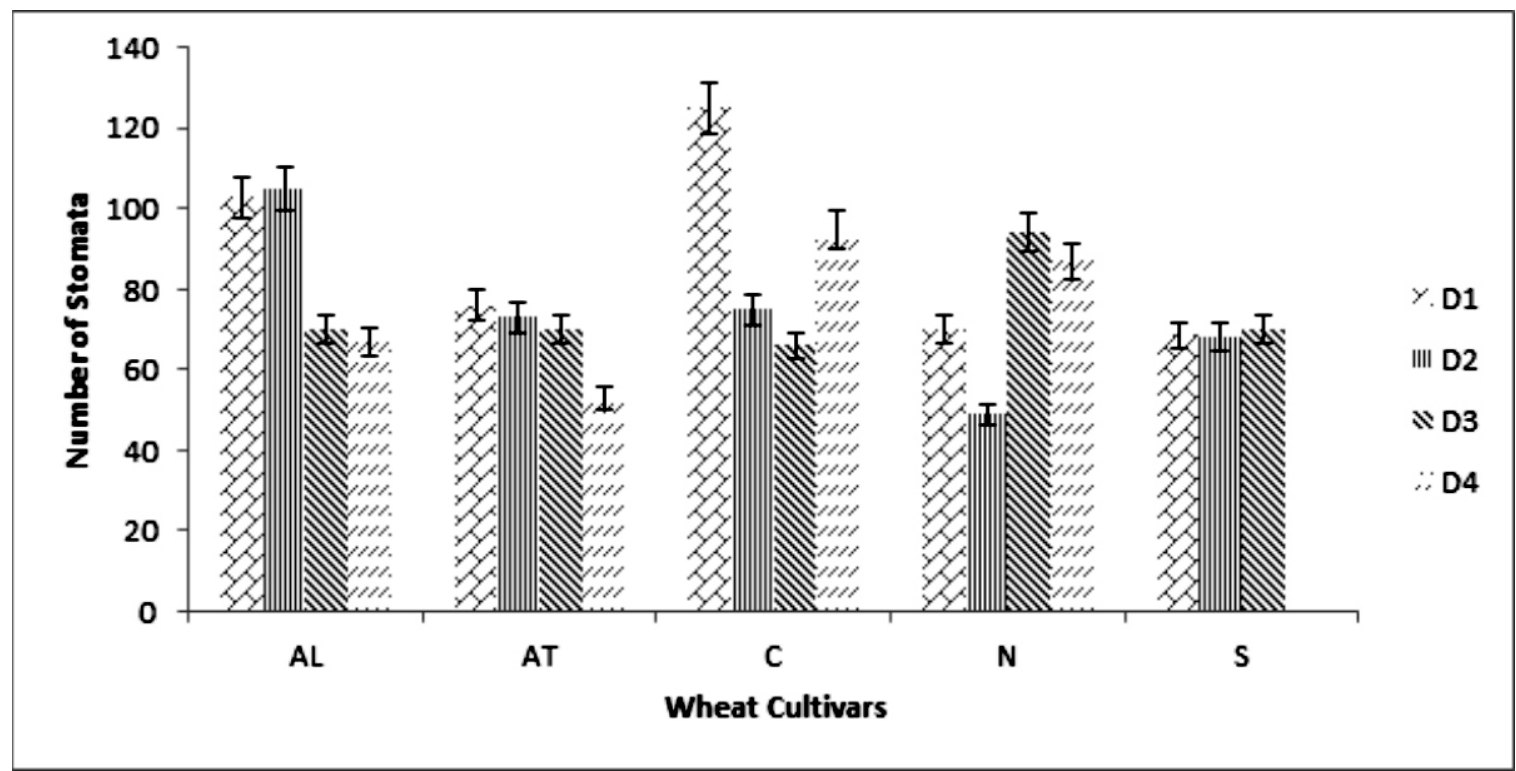

Figure 2: Response of Stomata to Drought stress per unit area of surface
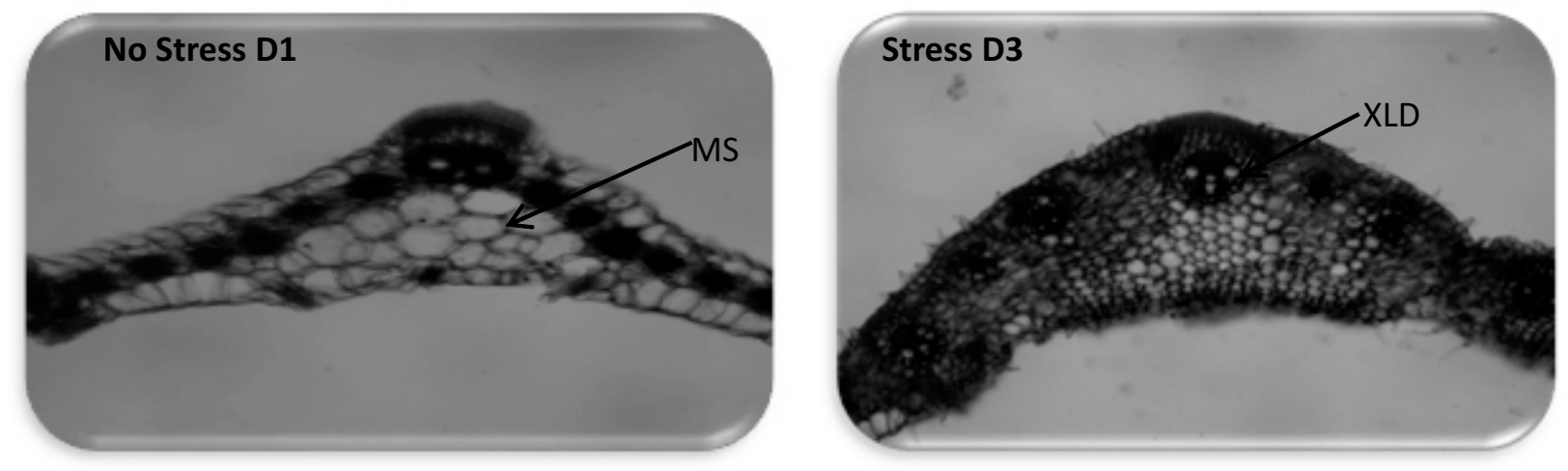

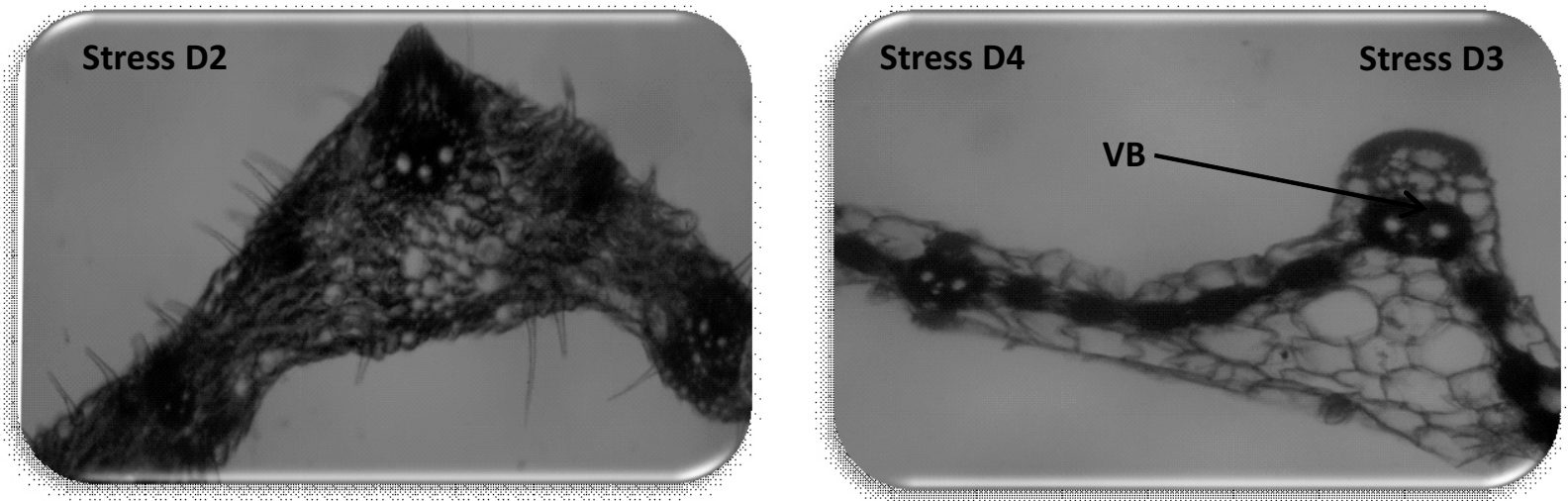

Figure 3: Internal structure of wheat Cettia cultivar under drought stress
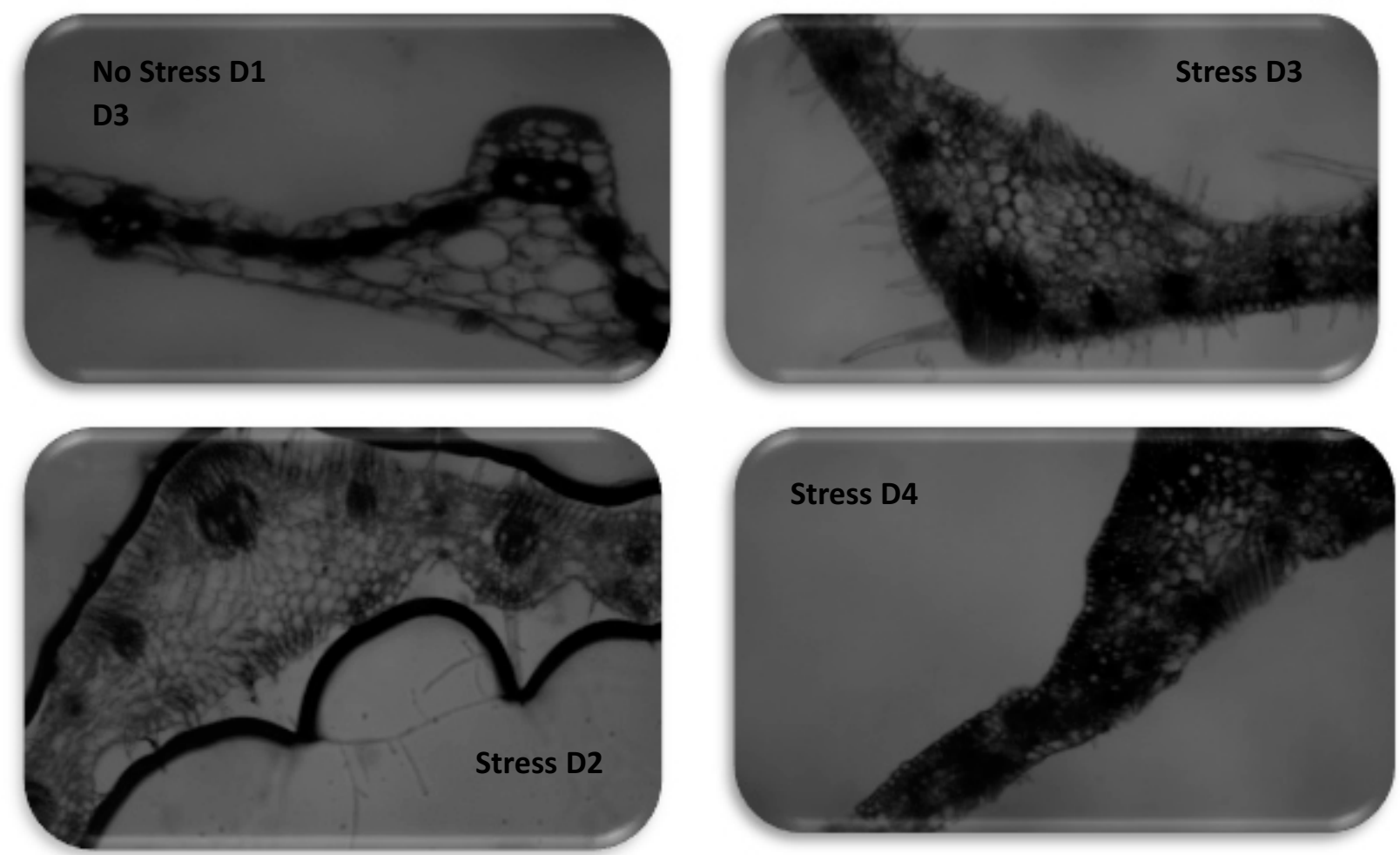

Figure 4: Internal structure of wheat Atila cultivar under drought stress

MS: Mesophyll thickness, XLD: Xylem Diameter, VB: Vascular Bundles
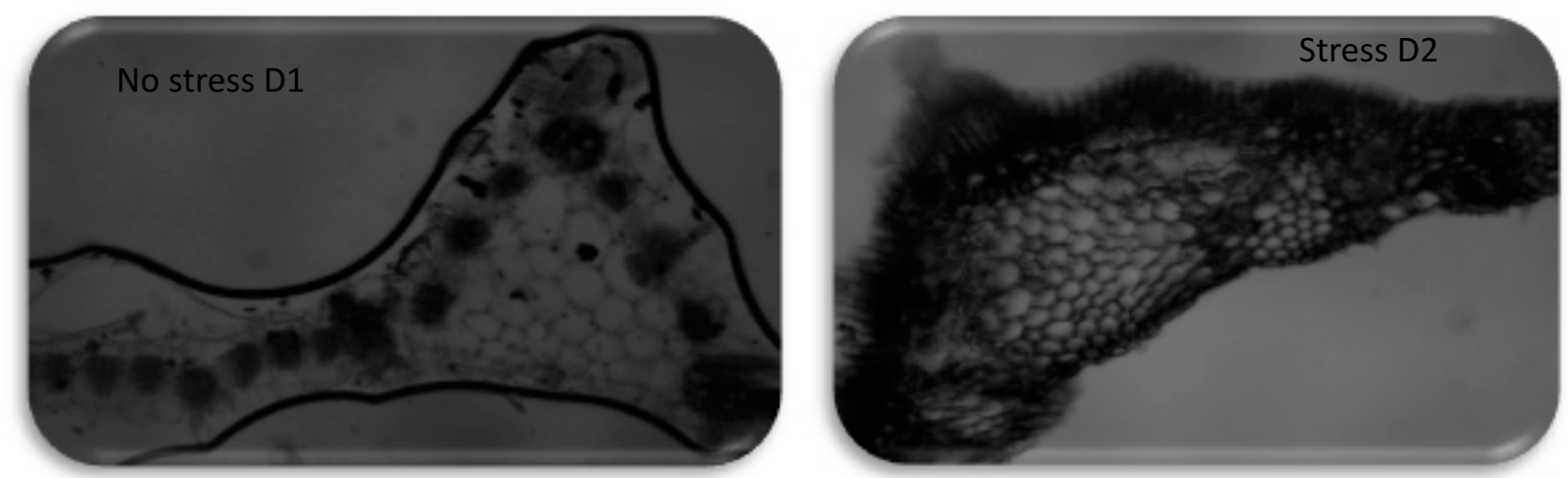

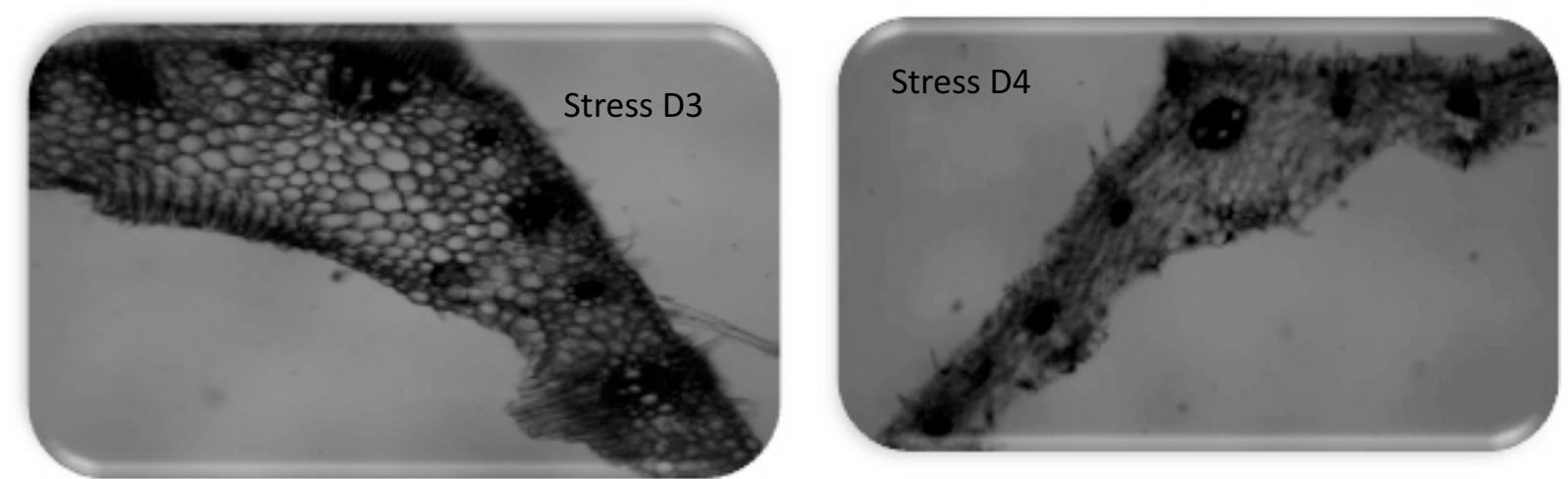

Fioure 5: Internal structure of wheat Alta cultivar under drouoht stress
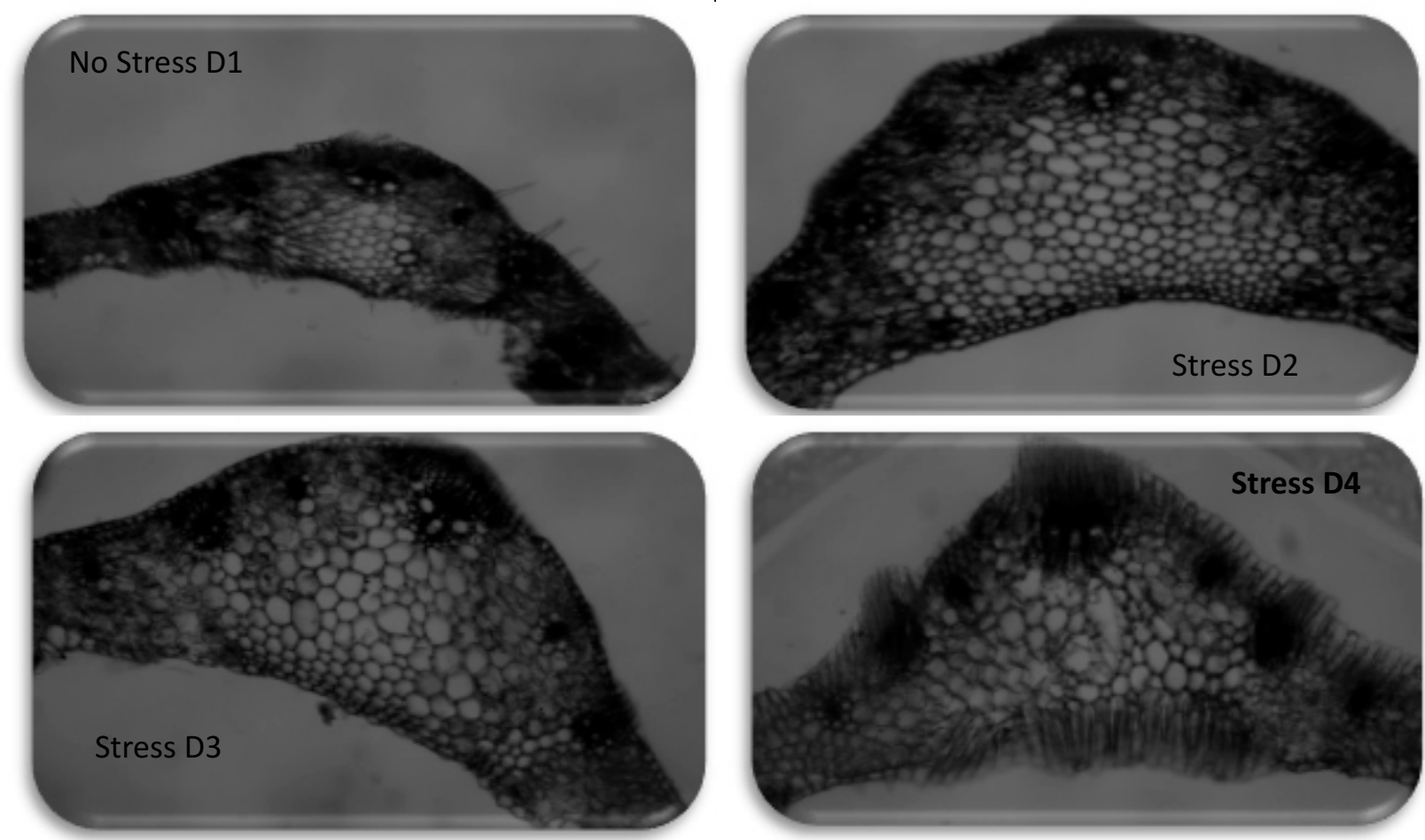

Figure 6: Internal structure of wheat NB cultivar under drought stress
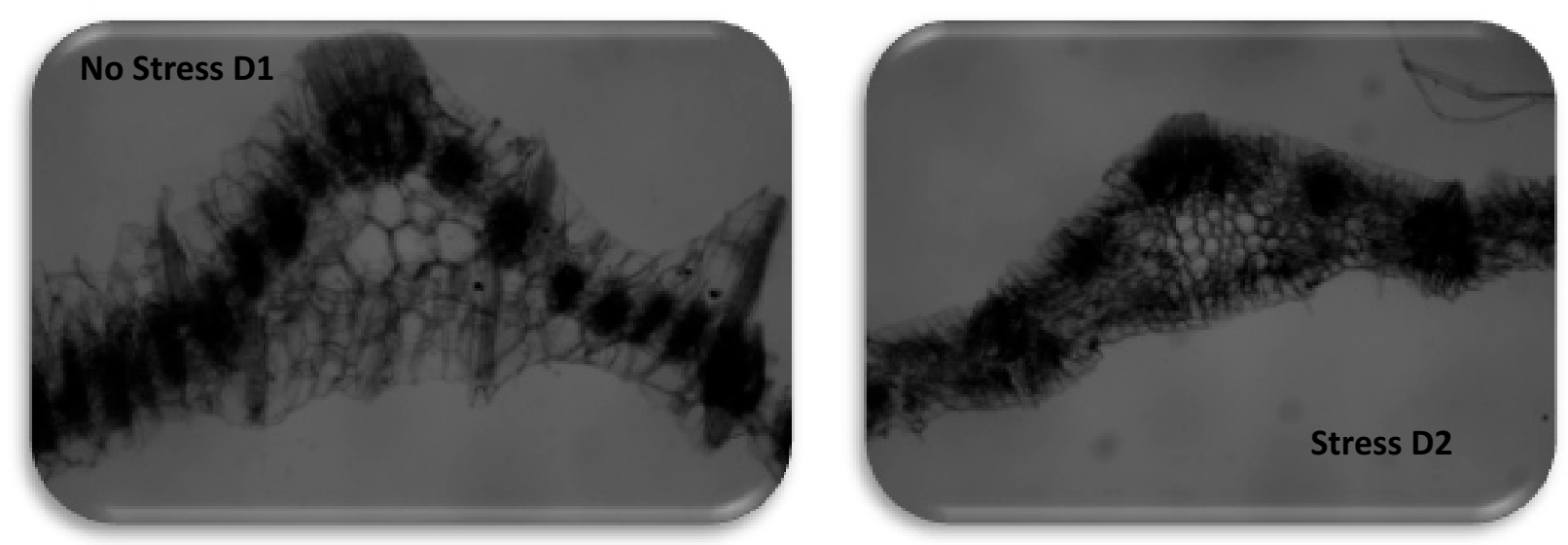

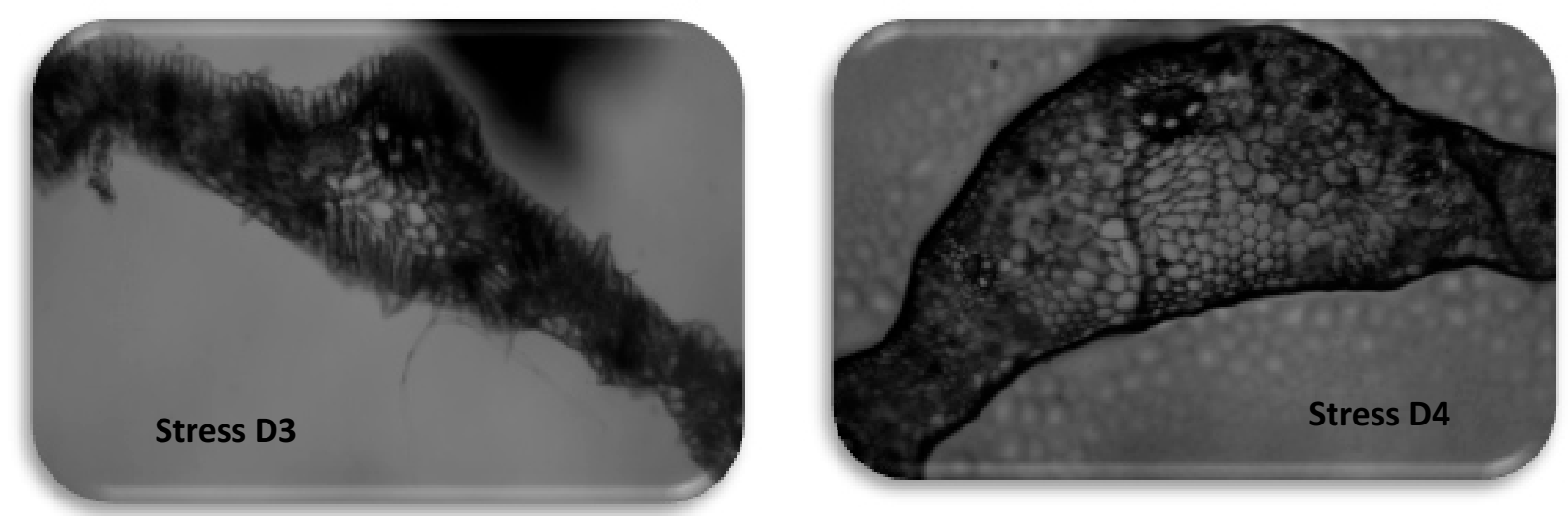

Figure 7: Internal structure of wheat Seri M82 cultivar under drought stress

\section{DISCUSSION}

Wheat plants developed greater number of unicellular non-glandular trichomes in response to drought stress. Greater number of trichomes helps to reduce the losses of water of vapour from the plants by humidifying the leaf surface thereby creating resistance to water flow (Traw and Dawson 2002). Furthermore, trichomes increased the tolerance level to drought by reducing absorbance of solar radiation, increasing relative humidity near the leaf surface and hence the maintenance of gradient water potential between leaf tissue and the surrounding air layer (Benz and Martin, 2006). During drought stress, wheat cultivar Atila showed the highest number of nonglandular trichomes.

Great number of trichomes present in these cultivars could have assisted the cultivars against oxidative stress. Greater number of trichomes protect living cells from damage caused by solar radiation (Skaltsa et al., 1994). The number of trichomes and stomata vary considerably among wheat cultivars. Variations in number of trichomes depend on the genotypes of Jatropha spp (Adulrahaman and Oladele, 2011) and also, tolerance strategies vary with genotype (Khakwani et al., 2012).

During drought stress, there were significant variations in size of mesophyll cells, xylem bundle sheaths and vascular bundles of wheat cultivars. Absence of intercellular spaces in the mesophyll cells is an indication of resistance to water flow in plants. Well-watered wheat plants have mesophyll cells with intercellular spaces. However, as they were subjected to drought stress, the mesophyll cells became wider with disappearance of intercellular spaces. Cettia cultivar had the widest xylem vessel. This made it more efficient in water absorption and providing water up from the root to the shoot of the plant. Though, there was little difference between the size of xylem tissue of cultivars Alta 84, Atila and Cettia. Drought tolerant cultivar Cettia had the widest and well compacted mesophyll cells, which suggested another strategy to prevent movement of water out of the plant cells, which would help to stabilize photosynthesis. This is in conformity with findings of Syvertsen et al. (1995). Photosynthetic assimilation rates were regulated by the intrinsic photosynthetic capacity of the mesophyll and by the conductance of $\mathrm{CO}_{2}$ from ambient air to the sites of carboxylation in the chloroplasts. Also, resistance to gas circulation depends mainly on the packing of the mesophyll cells (Marchi et al., 2008). Similarly, drought tolerant wheat accession Pak 15800 had maximally-increased mesophyll thickness and number of hairs under water stress (Hammed et al., 2012).

Generally, during drought stress, there would be stomata closure to adapt to severe drought stress, this mechanism is a common plant response to stress, but the extent and velocity of this response may also differ among species (Schulze and Hall, 1982). Stomata closures usually occur via the distress signal "abscisic acid" and lead to a decreased rate of transpiration from the mesophyll chloroplasts to the guard cells of the stomata during water stress conditions (Wright and Hiron, 1969).

\section{CONCLUSION}

Compactly arranged mesophyll cells, wider xylem, vascular bundles, bundle sheaths and greater 
number of trichomes were probably characteristics that contributed to Cettia cultivar's ability to tolerate drought stress than other cultivars.

\section{REFERENCE}

Adulrahaman, A.A. (2009). Morphology and epidermal adaptation to water stress in some ornamental plant species. Phd. Thesis, University of Ilorin, Ilorin Nigeria.

Adulrahaman, A.A. and Oladele, F.A. (2011). Response of trichome to water stress in two species of Jatropha. Insight Botany, 1(2):5-21.

Arve, L.E., Torre, S., Olsen, J.E. and Tanino, K.K. (2011). Stomatal Responses to Drought Stress and Air Humidity In Abiotic Stress in Plants - Mechanisms and Adaptations. Arun Shanker (Ed.), ISBN: 978-953-307-394-1, InTech Europe

Amzat, R., Haider, S., Nasreen, H., Aziz, F. and Riaz, M. (2009). A viable alternative mechanism in adapting the plants to heavy metal environment. Pak. J. Bot. 41(6):2729-2738.

Benz, B.W. and Martin, C.E. (2006). Foliar trichomes, boundary layers, and gas exchange in the species of epiphytic Tillandsia (Bromeliaceae). J Plant Physiol. 163:648-656

Gaston, L.A., Locke, M.A., Zablotowicz, R.M. and Reddy, K.N. (2011). Spatial variability of soil properties and weed populations in the Mississippi delta. Soil Sci Soc Am J. 65:449-459.

Hammed, M., Mansoor, U., Ashraf M. and Rao R. (2002). Variation in Leaf Anatomy in Wheat Germplasm from Varying Drought-Hit Habitats. International Journal of Agriculture \& Biology $4(1): 12-16$

Höglund, S. and Larsson, S. (2005). Abiotic induction of susceptibility in insectresistant willow. Entomol Exp Appl.115:89-96

Khakwani, A.A., Dennett, M.D., Munir, M. and Baloch, M.S. (2012). Wheat yield response to physiological limitations under water stress condition. The Journal of Animal \& Plant Sciences, 22(3): 773-
780

Løe, G., Tora “ng, P., Gaudeul, M.A. and Gren, J. (2007). Trichome production and spatiotemporal variation in herbivory in the perennial herb Arabidopsis lyrata. Oikos, 116:134-142

Marchi, S., Tognetti, R., Minnocci, A., Borghi, M. and Sebastiani, L. (2008). Variation in mesophyll anatomy and photosynthetic capacity during leaf development in a deciduous mesophyte fruit tree (Prunus persica ) and an ever-green sclerophyllous Mediterranean shrub (Olea europaea L.). Trees, 22: 559-571.

Nagata, T., Todoriki, S., Hayashi, T., Shibata, Y., Mori, M., Kanegae, H. and Kikuchi, S. (1999). Gamma-radiation induces leaf trichome formation in Arabidopsis. Plant Physiol. 120:113-119

Rajaman, S. (2011). Prospects and promise wheat breeding in the $21^{\text {st }}$ century. Euphytica;19:3-15.

Rockström, J., Barron, J., Brouwer, J., Galle, S. and de Rouw, A. (1999). On-farm spatial and temporal variability of soil and water in pearlmillet cultivation. Soil Sci Soc Am J. 63:1308-1319.

Schulze, E.D. and Hall, A.E. (1982). Stomatal responses to water loss and $\mathrm{CO}_{2}$ assimilation rates in plants of contrasting environments. In: Lange OL, Nobel PS, Osmond CB, Ziegler H (eds) Encyclopedia of plant physiology. Physiological plant ecology, vol 12B. Springer-Verlag, Berlin, pp 181-230.

Skaltsa, H., Verykokidou, E., Harvala, C., Krabourniotis, G. and Manetas, Y. (1994). UV-protective potential and flavonoid content of leaf hairs of Quercus ilex. Phytochemistry, 37:987-990

Southwood , S. R. (1986). Plant surfaces and insects - an overview. In: Juniper B, Southwood S.R. (eds) Insects and the plant surface. Arnold, London, pp 1-22.

Syvertsen, J.R., Lloyd, J., McConchie, C., Kriedemann, P.E. and Farquhar, G.D. (1995). On the relationship between leaf anatomy and $\mathrm{CO}_{2}$ diffusion through the mesophyll of hypostomatous leaves. Plant Cell Environ. 18: 149-157.

Traw, B.M. and Dawson, T.E. (2002). Reduced 
performance of two specialist herbivores (Lepidoptera: Pieridae, Coleoptera: Chrysomelidae) on new leaves of damaged black mustard plants. Environ Entomol. 31:714-722.

Werker, E. (2000). Trichome diversity and development. Adv Bot Res. 31:1-35

Wright, S.T.C. and Hiron, R.W.P. (1969). Abscisic acid, the growth inhibitor induced in detached wheat leaves by a period of wilting. Nature London 224:719-720. 